\title{
Control of Black Grass Bugs (Labops Hesperius Uhler) in Northern New Mexico
}

\author{
GEORGE W. DICKERSON
}

Highlight: Insecticides applied to improved wheatgrass pastures in northern New Mexico in the springs of 1976 and 1977 were all shown to reduce population of black grass bugs significantly $(P<.01)$. Herbage yields were decreased as much as $50 \%$ on untreated crested wheatgrass plots in 1976. Plots treated with trichlorofon produced significantly $(P<.05)$ higher herbage yields than the untreated plots. Malathion at rates as low as $354 \mathrm{~g} / \mathrm{ha}$ of active ingredient were effective in controlling this pest.

Black grass bugs (Labops hesperius Uhler) infest large acreages of improved wheatgrass (Agropyron sp.) pastures of northern New Mexico every year. Black grass bugs cause irregular yellow or white spots on the leaf blades of these grasses by sucking plant juices with their piercing-sucking mouthparts. Heavy infestations can cause considerable reduction in herbage production and even plant mortality during periods of prolonged drought (Knowlton and Roberts 1975).

$L$. hesperius adults average about $0.6 \mathrm{~cm}$. in length and are predominantly black in color, with a yellow or white edge around the outer margins of their wings. A single clump of grass may contain hundreds of these gregarious insects (Todd and Kamm 1974).

The exact number of hectares infested by black grass bugs in New Mexico is unknown, although most reports of their damage come from Rio Arriba and Sandoval counties in northern New Mexico. Large acreages of crested wheatgrass (Agropyron cristatum) have been planted in these counties. Since it is one of the preferred hosts of the black grass bugs, some crested wheatgrass seedings have been plowed up and reseeded in some areas to pubescent wheatgrass (Agropyron trichophorum), which seems to be more tolerant to black grass bug infestations.

To determine what insecticides might be effective in controlling black grass bugs in this area, several insecticides were screened on two sites in Rio Arriba County in the springs of 1976 and 1977. Insecticides included trichlorfon (Dylox 4), malathion Cythion 57), methyl parathion (Penncap M) and diazinon (Diazinon 500).

\section{Areas of Study}

The primary site of this investigation in 1976 and 1977 was on the Don Berryman Ranch, south of Cebolla, New Mexico, on Highway 84 . The treatments were applied to a 10 -year old stand of crested wheatgrass on a sandy loam soil. The elevation was $2,286 \mathrm{~m}$, with an average annual precipitation of $44 \mathrm{~cm}$.

The Grace Davis Ranch, near Llaves, New Mexico, was included in the study in 1977 . The crested wheatgrass at this site was 10 to 12 years old. The soil was a sandy loam occurring at an elevation of $1,737 \mathrm{~m}$ and an average annual precipitation of $38 \mathrm{~cm}$.

\section{Materials and Methods}

In 1976, the insecticide screening trials were set up on the Berryman Ranch in a randomized, complete block design with three replications per treatment. Individual plots were 0.07 ha in size. Treatments were applied April 20, with a trailer-mounted, boom-type spray rig. Approximately $94 \mathrm{~L}$ of water/ha ( 9.9 gal.) acre) were applied for each treatment.

Insecticides applied to these plots included trichlorfon $(1,134 \mathrm{~g}$ $\mathrm{ai} / \mathrm{ha})$; malathion $(1,417 \mathrm{~g}$ a.i./ ha); and methyl parathion $(567 \mathrm{~g}$ a.i./ha). These rates are equivalent to $2 \mathrm{pt}$. of each commercial

The authors is instructor, Department of Agricultural Services, New Mexico State University, Las Cruces.

Manuscript received January 17, 1978.

product per acre, which are the labeled recommendations for these products for black grass bugs or other pests on rangeland. Trichlorfon is the only chemical labeled for use against black grass bugs at this time. Similar rates were also found effective against black grass bugs in Wyoming (Burkhardt 1974).

Black grass bug population densities were determined by randomly selecting clumps of grass and estimating the number of black grass bugs present. This was extrapolated to the number of black grass bugs present in a square meter $\left(\mathrm{m}^{2}\right)$ based on grass cover. These counts were made on April 20, May 5, and May 24, 1976. A rotary mower was used to make diagonal cuts across each plot on May 24 to determine the relative wet-weight herbage yields for each treatment. The blade was set at approximately $10 \mathrm{~cm}$ above ground level. No dry-weight yields were determined. The data collected were subjected to an analysis of variance and the means were compared with Duncan's new multiple range test. Cattle were not allowed to graze the area.

In 1977, the insecticide screening trials were set up on both the Berryman and Davis ranches. A randomized complete block design was used, with two replications per treatment at each site. Plots averaged $12 \mathrm{~m}$ in width and varied in length. Treatments were applied on April 27 at the Davis Ranch and on April 28 at the Berryman Ranch. Treatments were applied using a single, flooding, fan-type nozzle mounted about $10 \mathrm{~cm}$ above the tailgate of a pickup. Approximately $189 \mathrm{~L}$ of water per ha ( 20 gal./acre) were applied with this rig pumping out of an oil drum. Insecticide treatments included trichlorfon $(1,134 \mathrm{~g}$ a.i./ ha $)$, diazinon $(1,134 \mathrm{~g}$ a.i./ha), and two rates of malathion $(1,417$ and $354 \mathrm{~g}$ a.i./ ha).

Black grass bug counts were made in the same manner as the year before and the data were analyzed and ranked in the same manner. No information was collected on herbage yields.

\section{Results}

In 1976, the black grass bugs hatched out immediately after snow melt. Insect samples collected showed a mixed population of black grass bugs and false chinch bugs (Nysius ericae). Initial counts averaged about 3,767 black grass bugs $/ \mathrm{m}^{2}$ (Table 1 ).

Insect populations were significantly $(P<.01)$ reduced with the use of insecticides, although there were no significant differences between the individual insecticides (Table 1). Trichlorfon and methyl parathion seemed to have some carry-over effect on black grass bug populations when counts were made on May 24. There were no significant differences in black grass bug densities $(P<.01)$ between malathion plots and check plots on this date. The popu-

Table 1. Rates of application, black grass bug counts and fresh herbage yields for various insecticide treatments used to control black grass bugs on the Don Berryman Ranch, Rio Arriba County, New Mexico, 1976.

\begin{tabular}{|c|c|c|c|c|c|}
\hline \multirow[t]{2}{*}{ Treatment } & \multirow{2}{*}{$\begin{array}{c}\text { Rate } \\
\text { (g.a.i./ha) }\end{array}$} & \multicolumn{3}{|c|}{$\begin{array}{c}\text { Number of grass bugs } / \mathrm{m}^{2} \\
\text { of grass cover }\end{array}$} & \multirow{2}{*}{$\begin{array}{l}\text { Herbage } \\
\text { production } \\
\text { (kg of wet } \\
\text { matter/ha) }\end{array}$} \\
\hline & & $4 / 20 / 76$ & $5 / 5 / 76$ & $5 / 24 / 76$ & \\
\hline Check & - & 3767 & $2842 \mathrm{a}^{2}$ & $122 \mathrm{c}^{2}$ & $103 \mathrm{e}^{3}$ \\
\hline Trichlorfon & 1134 & 3767 & $2 \mathrm{~b}$ & $57 \mathrm{~d}$ & $239 \mathrm{f}$ \\
\hline Malathion & 1417 & 3767 & $129 \mathrm{~b}$ & $100 \mathrm{c}$ & $191 \mathrm{ef}$ \\
\hline Methyl parathion ${ }^{1}$ & 567 & 3767 & $0 \mathrm{~b}$ & $57 \mathrm{~d}$ & $173 \mathrm{ef}$ \\
\hline
\end{tabular}

1 Methyl parathion (Penncap M) has a 15-day grazing restriction.

${ }^{2}$ Numbers followed by the same letter in a column are not significantly $(P<.01)$ different (Duncan's new multiple range test).

${ }^{3} P<.05$ (Duncan's new multiple range test). 
Table 2. Rates of application and average black grass bug counts for various insecticide treatments on two ranches in Rio Arriba County, New Mexico, 1977.

\begin{tabular}{|c|c|c|c|}
\hline \multirow{2}{*}{ Treatment } & \multirow{2}{*}{$\begin{array}{l}\text { Rate } \\
\text { (g a.i./ha) }\end{array}$} & \multicolumn{2}{|c|}{$\begin{array}{c}\text { Number of black grass bugs } / \mathrm{m}^{2} \\
\text { of grass cover }\end{array}$} \\
\hline & & $4 / 27-28 / 77$ & $5 / 5 / 77$ \\
\hline Check & - & 2228 & $3535 \mathrm{a}^{1}$ \\
\hline Malathion & 354 & 2228 & $6 \mathrm{~b}$ \\
\hline Malathion & 1417 & 2228 & $2 b$ \\
\hline Trichlorfon & 1134 & 2228 & $3 b$ \\
\hline Diazinon & 1134 & 2228 & $3 \mathrm{~b}$ \\
\hline
\end{tabular}

Numbers followed by the same letter in a column are not significantly $(P<.01)$ different (Duncan's new multiple range test).

lation density of black grass bugs on the check plots had decreased considerably by this date.

Grass in the untreated plots was notably bleached-out in color. These plants were stunted, while treated plants were vigorous and green. Unsprayed plots showed over a 50\% reduction in herbage production, as compared to those plots treated with trichlorfon (Table 1). Malathion at $1,417 \mathrm{~g} / \mathrm{ha}$ (a.i.) and methyl parathion at $567 \mathrm{~g} /$ ha (a.i.) increased herbage production slightly, but not sionificantlv $(P<.05)$.
In 1977, all insecticide-treated plots showed a highly significant $(P<.01)$ decrease in black grass bug populations over the check plots (Table 2). No significant differences $(P<.01)$ were noted between the various insecticides applied or even between the rates of malathion. Untreated plots on the Berryman Ranch averaged about one and a half times more black grass bugs per meter than those on the Davis Ranch.

The rates of insecticide used in this experiment are the labeled rates used to control other range pests such as grasshoppers. More work needs to be done to determine whether lower rates may be just as effective, to make spraying more economical. The long-range effects of spraying on this pest must also be studied to determine whether a spray program may be effective for several years, rather than just for one season.

\section{Literature Cited}

Burkhardt, C. C. 1974. Grass bug control in grass and wheat. Agr. Exp. Sta., Univ. of Wyoming. Res. J. 82. March.

Knowlton, G. F., and Reed S. Roberts. 1974. "Grass Bugs". Entomology Newsletter. Utah State University. No. 64. April.

Todd, J. G., and J. A. Kamm. 1974. Biology and impact of a grass bug Lahops hesperus Uhler in Oregon rangeland. J. Range Manage. 27:453458. 